\title{
PERBEDAAN PENGARUH PENGGUNAAN ALAT KONTRASEPSI IUD DAN SUNTIK TERHADAP SIKLUS HAID PEREMPUAN DI KECAMATAN MARPOYAN DAMAI PEKANBARU
}

\author{
Ikhwani Ratna \& Irdayanti \\ Fakultas Ekonomi UIN Suska Riau \\ Email: weni_27@ymail.com
}

\begin{abstract}
This study aims to determine the difference of the menstrual cycle between the user of IUD contraception and the inject contraception and to know the side effects of these two devices towards the women in Marpoyan Damai the District, Pekanbaru. The population of this study is all the new users of IUD and inject contraception in Merpoyan Damai disctrikck, Pekanbaru, from January to March 2012, 69 women are using IUD and 564 women using injection. This study is non-experimental descriptive analytic cross sectional approach and Slovin technique is used for taking the sample. Data is analyzed using by statistical techniques to an independent $t$-test. The results suggest $P$ is 0.006 with significantly less than 0.05, it means that there is a significant differences between menstrual cycles of women who used the IUD contraception and who usess injection contraception.
\end{abstract}

Kata Kunci: alat kontrasepsi, IUD, suntik, siklus haid 


\section{PENDAHULUAN}

Keluarga Berencana (KB) merupakan salah satu pelayanan kesehatan preventif yang paling dasar dan utama bagi perempuan, meskipun tidak selalu diakui demikian. Peningkatan dan perluasan pelayanan KB merupakan salah satu usaha untuk menurunkan angka kesakitan dan kematian ibu yang sedemikian tinggi akibat kehamilan dan melahirkan. Untuk optimalisasi manfaat kesehatan KB, pelayanan tersebut harus disediakan bagi perempuan dengan cara menggabungkan dan memenuhi kebutuhan pelayanan kesehatan reproduksi utama dengan yang lainnya.

Ketersediaan layanan KB bagi perempuan terdapat dalam beberapa metode, dan perempuan harus dapat menimbang berbagai factor dalam memilih metode KB yang sesuai bagi dirinya, termasuk status kesehatan mereka, efek samping potensial suatu metode, konsekuensi terhadap kehamilan yang tidak diinginkan, besarnya keluarga yang diinginkan, kerjasama pasangan, dan norma budaya mengenai kemampuan mempunyai anak.

Dengan semakin berkembangnya program KB yang dicanangkan oleh pemerintah, alat kontrasepsi pun semakin berkembang. Berbagai pilihan alat kontrasepsi ditawarkan kepada masyarakat. Dari mulai yang sederhana sampai yang permanen/mantap, yaitu mulai pil, suntik, spiral dan Intra Uterine Device (IUD). Ada jenis kontrasepsi lain, yaitu vasektomi untuk pria dan tubektomi untuk perempuan. Namun 2 jenis alat kontrasepsi ini masih jarang dipilih oleh masyarakat, sebab dengan memiliki alat kontrasepsi mantap tersebut maka seseorang tidak bisa lagi memiliki anak. Menurut data pemerintah (sampai dengan bulan Maret 2012) kontrasepsi suntik paling banyak digunakan oleh perempuan di Provinsi Riau 49.89\%, pil KB sebanyak 33.93\%, IUD 2.25\%, implant 3.28\% dan sterilisasi Metode Operasi Wanita (MOW) 0.97\% dan Metode Operasi Pria (MOP) $0.11 \%$

Alat kontrasepsi IUD dan suntikan mempunyai permasalahan atau efek samping. Efek samping yang paling utama adalah gangguan pola haid. Pemakai KB IUD, baik "copper $T$ " atau jenis lainnya, sering mengalami perubahan pada pola haidnya. Lama haid menjadi lebih panjang, beberapa diantaranya didahului dan diakhiri oleh perdarahan bercak. Jumlah haid menjadi lebih banyak dan datangnya haid (siklus) menjadi lebih pendek, sehingga seakan-akan haidnya datang 2 kali dalam kurun waktu 1 bulan (30 hari). Panjang siklus bervariasi, dari 23 hari atau kurang untuk siklus pendek, dan lebih dari 35 hari untuk siklus panjang. Efek samping pemasangan IUD yang lain termasuk diantaranya: rasa 
tidak enak di perut, perdarahan per vagina atau spotting, infeksi perdarahan yang banyak, kram, infeksi, kemandulan dan kebocoran rahim.

Pemakaian KB suntik mengalami beberapa permasalahan, yaitu gangguan pola haid, kenaikan berat badan dan sakit kepala. Gangguan pola haid yang terjadi tergantung pada lama pemakaian. Gangguan pola haid yang terjadi adalah perdarahan bercak, perdarahan irreguler, amenore dan perubahan dalam frekuensi, lama dan jumlah darah yang hilang. Efek samping lainnya antara lain, sering menaikkan Berat Badan, dapat menyebabkan (tidak pada semua akseptor) sakit kepala, nyeri payudara, "moodiness", jerawat, kurangnya libido seksual, rambut rontok.

Penelitian ini bertujuan untuk mengetahui perbedaan siklus haid antara perempuan yang menggunakan alat kontrasepsi IUD dengan kontrasepsi suntik di Kecamatan Marpoyan Damai Kota Pekanbaru, dan menganalisis efek samping penggunaan alat kontrasepsi pada perempuan dari sudut pandang gender.

Populasi yang digunakan dalam penelitian ini adalah peserta baru KB yang menggunakan alat kontrasepsi IUD dan suntik yang melakukan pemasangan alat kontrasepsi pada klinik KB atau Puskesmas di Kecamatan Marpoyan Damai Kota Pekanbaru s/d bulan Maret 2012, yaitu Peserta KB baru IUD sebanyak 69 orang dan peserta KB baru suntikan sebanyak 564 orang. Adapun rinciannya sebagai berikut:

Tabel 1

Jumlah Peserta KB Baru IUD dan Suntik di Kecamatan Marpoyan Damai Pekanbaru dari Januari s/d Maret 2012

\begin{tabular}{|c|c|c|c|c|c|c|}
\hline $\begin{array}{l}\text { Kode } \\
\text { Provinsi }\end{array}$ & $\begin{array}{l}\text { Klinik } \\
\text { KB }\end{array}$ & $\begin{array}{l}\text { Peserta } \\
\text { KB Baru } \\
\text { IUD }\end{array}$ & $\%$ & $\begin{array}{l}\text { Peserta KB } \\
\text { Baru } \\
\text { Suntikan }\end{array}$ & $\%$ & $\begin{array}{l}\text { Jumlah } \\
\text { Peserta } \\
\text { KB Baru }\end{array}$ \\
\hline 1471001 & $\begin{array}{l}\text { KKB } \\
\text { Langsat }\end{array}$ & 5 & $4.46 \%$ & 57 & $50.89 \%$ & 112 \\
\hline 1471034 & $\begin{array}{l}\text { PKM.SP. } \\
\text { Tiga }\end{array}$ & 1 & $0.23 \%$ & 274 & $63.72 \%$ & 430 \\
\hline 1471054 & $\begin{array}{l}\text { Puskesm } \\
\text { as } \\
\text { Garuda }\end{array}$ & 15 & $4.16 \%$ & 220 & $60.94 \%$ & 361 \\
\hline 1471073 & $\begin{array}{l}\text { RSI } \\
\text { Andini }\end{array}$ & 20 & $58.82 \%$ & 0 & $0.00 \%$ & 34 \\
\hline 1471084 & $\begin{array}{l}\text { RS. Eka } \\
\text { Hospital }\end{array}$ & 28 & $53.85 \%$ & 13 & $25.00 \%$ & 52 \\
\hline
\end{tabular}




\begin{tabular}{llllll}
\hline Jumlah & 69 & $6,98 \%$ & 564 & $57,03 \%$ & 989 \\
\hline
\end{tabular}

Sumber: BKKBN Provinsi Riau 2012

Sampel adalah sebagian dari jumlah dan karakteristik yang dimiliki oleh populasi tersebut. ${ }^{1}$ Untuk sampel peserta KB baru IUD diambil dengan menggunakan teknik total populasi, dimana semua populasi dipilih sebagai sampel. Sedangkan peserta KB baru suntik memiliki populasi yang jumlahnya lebih dari seratus orang, untuk pengambilan sampelnya digunakan teknik random, yaitu pemilihan sampel secara acak dari anggota populasi dimana semua anggota populasi mempunyai kesempatan yang sama untuk diambil sebagai sampel dimana ditentukan jumlahnya dengan menggunakan teori yang dikemukan oleh slovin yaitu dengan rumus :

$$
n=N /\left(1+N e^{\wedge} 2\right)
$$

Keterangan:

$n=$ Number of samples (jumlah sampel)

$N=$ Total population (jumlah seluruh anggota populasi)

$e=$ Error tolerance (toleransi terjadinya galat; taraf signifikansi; untuk

sosial dan pendidikan lazimnya 0,1$) \rightarrow(\wedge 2=$ pangkat dua $)$

Dengan menggunakan rumus diatas, maka jumlah sampel untuk semua perempuan yang menggunakan alat kontrasepsi IUD adalah 69 orang, dan suntik yang masing-masing berjumlah 85 dengan kriteria inklusi sebagai berikut: Pertama, masih menggunakan alat kontrasepsi IUD dan suntik. Kedua, perempuan usia subur yang menggunakan IUD dan suntik. Ketiga, mampu berkomunikasi dengan baik. Keempat, bersedia menjadi responden. Kelima, bertempat tinggal di Kecamatan Marpoyan Damai Kota Pekanbaru.

Penelitian bersifat non eksperimental yaitu deskriptif analitik dengan menggunakan pendekatan cross sectional dimana data yang menyangkut variabel bebas dan variabel terikat diambil dalam waktu yang bersamaan dengan tujuan untuk mencari hubungan antara dua variabel ${ }^{2}$ dan dilakukan di Kecamatan Marpoyan Damai Kota Pekanbaru pada bulan Maret 2012.

Instrumen penelitian yang digunakan adalah kuesioner dan check list. Kuesioner merupakan suatu bentuk pengumpulan data yang digunakan apabila jumlah responden banyak dan responden dapat membaca dengan baik dan mudah digunakan. Data yang diperoleh dikategorikan sebagai data factual. ${ }^{3}$ Pada penelitian ini dibuat sebuah kuesioner untuk mengukur penggunaan alat kontrasepsi IUD terhadap siklus haid dan penggunaan kontrasepsi suntik terhadap siklus haid. 
Penelitian diberikan dengan rentang nilai kuesioner yang dibagikan kepada responden dalam bentuk pertanyaan tertutup. Untuk mengumpulkan data mengenai siklus haid pada responden menggunakan check list. Check list digunakan untuk mengetahui karakteristik haid yang dialami oleh responden dalam bentuk pertanyaan tertutup.

Setelah data terkumpul,dilakukan pengolahan data dengan langkah-langkah sebagai berikut: Pertama, Editing yaitu memeriksa data yang telah dikumpulkan berasal dari responden. Kedua, Coding yaitu memberi tanda untuk memudahkan dalam pengolahan data. Ketiga, Tabulating yaitu data disusun dalam bentuk tabel kemudian dianalisa dan disusun, disatukan berupa laporan hasil penelitian dan kesimpulan.

Pengolahan data dilakukan dengan komputer menggunakan proram SPSS. Analisa statistik yang digunakan adalah: Pertama, Analisa Univariat. Analisa dilakukan terhadap masing-masing variabel hasil penelitian, penyajian dalam bentuk distribusi frekuensi dan prosentase dari tiap variabel. data disajikan dalam bentuk nominal. Kedua, Analisa Bivariat. Analisa dilakukan untuk menyatakan kekuatan hubungan antara kedua variabel, yaitu variabel independent dan variabel dependent.

\section{PEMBAHASAN}

\section{Alat Kontrasepsi}

Kontrasepsi berasal dari kata kontra yang berarti mencegah atau melawan, sedangkan konsepsi adalah pertemuan antara sel telur yang matang dan sel sperma yang mengakibatkan kehamilan. Maksud dari kontrasepsi adalah menghindari/mencegah terjadinya kehamilan sebagai akibat pertemuan antara sel telur yang matang dengan sel sperma. Jenisjenis kontrasepsi yang lazim digunakan adalah kondom, spermatisida, Vagina Diafragma, Pil KB, Suntik KB, Susuk KB (Implant), IUD (Spiral), dan IUS.

\section{Kondom}

Kondom adalah salah satu alat kontrasepsi yang terbuat karet/lateks, berbentuk tabung. Penggunaan kondom cukup efektif selama digunakan secara tepat dan benar. Kegagalan kondom dapat diperkecil dengan menggunakannya secara tepat, yaitu gunakan pada saat penis sedang ereksi dan dilepaskan sesudah ejakulasi. Alat kontrasepsi ini paling mudah didapat serta tidak merepotkan. Kegagalan biasanya terjadi bila kondom robek karena kurang hati-hati atau karena tekanan pada saat ejakulasi sehingga terjadi perembesan. 
Spermatisida

Kontrasepsi ini merupakan senyawa kimia yang dapat melumpuhkan sampai membunuh sperma. Bentuknya bisa busa, jeli, krim, tablet vagina, tablet, atau aerosol. Penggunaan alat ini dapat dilakukan setelah kira kira 5-10 menit hubungan seksual, dengan memasukkan alat ini ke dalam vagina. Ketika memasukkannya kedalam vagina harus menggunakan alat yang telah disediakan dalam kemasan. Sangat tidak diperbolehkan menggunakan tangan. Kegagalan sering terjadi karena waktu larut yang belum cukup, jumlah spermatisida yang digunakan terlalu sedikit atau vagina sudah dibilas dalam waktu kurang dari 6 jam usai senggama.

\section{Vagina Diafragma}

Lingkaran cincin dilapisi karet fleksibel ini akan menutup mulut rahim bila dipasang dalam liang vagina 6 jam sebelum senggama. Efektifitasnya alat kontrasepsi ini bisa menurun bila terlalu cepat dilepas kurang dari 8 jam setelah senggama. Diafragma digunakan jika akan berhubungan seksual. Setelah itu bisa dilepas lagi atau tetap pada tempatnya. Karena bahannya lebih tebal dari kondom, kontrasepsi ini sangat kecil kemungkin terjadi bocor.

\section{Pil KB}

Keuntungan pil ini adalah tetap membuat haid teratur, mengurangi kram atau sakit saat menstruasi. Kesuburan dapat kembali pulih dengan cara menghentikan pemakaian pil ini. Pil bertujuan meningkatkan efektifitas, mengurangi efek samping, dan meminimalkan keluhan. Ada yang hanya mengandung hormon progesterone saja, ada pula kombinasi antara hormon progesteron dan estrogen. Cara menggunakannya, diminum setiap hari secara teratur. Ada dua cara meminumnya yaitu sistem 28 dan sistem 22/21. Untuk sistem 28, pil diminum terus tanpa pernah berhenti ( 21 tablet pil kombinasi dan 7 tablet plasebo). Sedangkan sistem 22/21, minum pil terus menerus, kemudian dihentikan selama 7-8 hari untuk mendapat kesempatan menstruasi. Jadi, dibuat dengan pola pengaturan haid (sekuensial).

\section{Suntik KB}

Jenis kontrasepsi ini pada dasarnya mempunyai cara kerja seperti pil. Kontrasepsi suntikan mengandung hormon sintetik. Penyuntikan ini dilakukan 2-3 kali dalam sebulan. Suntikan setiap 3 bulan *(Depoprovera $)^{*}$, setiap 10 minggu ${ }^{*}(\text { Norigest })^{*}$, dan setiap bulan 
${ }^{*}(\text { Cyclofem })^{*}$. Salah satu keuntungan suntikan adalah tidak mengganggu produksi ASI. Pemakaian hormon ini juga bisa mengurangi rasa nyeri dan darah haid yang keluar.

\section{Susuk KB (Implant)}

Implant atau susuk KB adalah kontrasepsi dengan cara memasukkan tabung kecil di bawah kulit pada bagian tangan yang dilakukan oleh dokter. Tabung kecil berisi hormone tersebut akan terlepas sedikit-sedikit, sehingga mencegah kehamilan. Susuk dipasang seperti kipas dengan enam buah kapsul. Di dalamnya berisi zat aktif berupa hormon atau Levonorgestrel. konsep kerjanya menghalangi terjadinya ovulasi dan menghalangi migrasi sperma. Pemakaian susuk dapat diganti setiap 5 tahun *(Norplant)* dan 3 tahun *(Implanon)*. Sekarang ada pula yang diganti setiap tahun. Penggunaan kontrasepsi ini biayanya ringan. Pencabutan bisa dilakukan sebelum waktunya jika memang ingin hamil lagi. Efektifitasnya, dari 10.000 pasangan, ada 4 perempuan yang hamil dalam setahun. Efek sampingnya berupa gangguan menstruasi, haid tidak teratur, bercak atau tidak haid sama sekali. Kecuali itu bisa menyebabkan kegemukan, ketegangan payudara, dan liang senggama terasa kering. Kendala lainnya dalam pencabutan susuk yaitu sulit dikeluarkan karena mungkin waktu pemasangannya terlalu dalam. Hal tersebut dapat menimbulkan infeksi.

\section{IUD (Spiral)}

Intrauterine Device atau biasa juga disebut spiral karena bentuknya memang seperti spiral. Teknik kontrasepsi ini adalah dengan cara memasukkan alat yang terbuat dari tembaga kedalam rahim. Kontrasepsi tersebut jadi pilihan karena kenyamanannya. Alat kontrasepsi ini dimasukkan ke dalam rahim oleh dokter dengan bantuan alat. Benda asing dalam rahim ini akan menimbulkan reaksi yang dapat mencegah bersarangnya sel telur yang telah dibuahi di dalam rahim. Alat ini bisa bertahan dalam rahim selama 2-5 tahun, tergantung jenisnya, dan dapat dibuka sebelum waktunya. Keuntungannya, alat ini bisa dipakai untuk jangka panjang. Bahkan sama sekali tidak mengganggu produksi ASI jika ibu sedang menyusui.

\section{IUS}

IUS atau Intra Uterine System adalah bentuk kontrasepsi terbaru yang menggunakan hormon progesteron sebagai ganti logam. Cara kerjanya sama dengan IUD tembaga, ditambah dengan beberapa nilai 
plus seperti lebih tidak nyeri dan kemungkinan menimbulkan pendarahan lebih kecil dan haid menjadi lebih ringan (volume darah lebih sedikit) dan waktu haid lebih singkat.

\section{Menstruasi/Haid}

Haid adalah pelepasan dinding rahim (endometrium) yang disertai dengan pendarahan dan terjadi setiap bulan, kecuali pada saat kehamilan. Haid yang terjadi terus menerus setiap bulannya disebut sebagai siklus menstruasi. Haid biasanya terjadi pada usia 11 tahun dan berlangsung hingga menopause (biasanya terjadi sekitar usia 45 - 55 tahun). Normalnya, haid berlangsung selama 3 - 7 hari.

Seorang perempuan memiliki 2 ovarium, masing-masing menyimpan sekitar 200,000 hingga 400,000 telur yang belum matang/folikel (follicles). Normalnya, hanya satu atau beberapa sel telur yang tumbuh setiap periode haid dan sekitar hari ke 14 sebelum haid berikutnya, ketika sel telur tersebut telah matang maka sel telur tersebut akan dilepaskan dari ovarium dan kemudian berjalan menuju tuba falopi untuk kemudian dibuahi. Proses pelepasan ini disebut dengan "OVULASI".

Pada permulaan siklus, sebuah kelenjar didalam otak melepaskan hormon yang disebut Follicle Stimulating Hormone (FSH) kedalam aliran darah sehingga membuat sel-sel telur tersebut tumbuh didalam ovarium. Salah satu atau beberapa sel telur kemudian tumbuh lebih cepat daripada sel telur lainnya dan menjadi dominan hingga kemudian mulai memproduksi hormon yang disebut estrogen yang dilepaskan kedalam aliran darah. Hormone estrogen bekerjasama dengan hormone FSH membantu sel telur yang dominan tersebut tumbuh dan kemudian memberi signal kepada rahim agar mempersiapkan diri untuk menerima sel telur tersebut. Hormon estrogen tersebut juga menghasilkan lendir yang lebih banyak di vagina untuk membantu kelangsungan hidup sperma setelah berhubungan intim.

Ketika sel telur telah matang, sebuah hormon dilepaskan dari dalam otak yang disebut dengan Luteinizing Hormone (LH). Hormon ini dilepas dalam jumlah banyak dan memicu terjadinya pelepasan sel telur yang telah matang dari dalam ovarium menuju tuba falopi. Jika pada saat ini, sperma yang sehat masuk kedalam tuba falopi tersebut, maka sel telur tersebut memiliki kesempatan yang besar untuk dibuahi. 


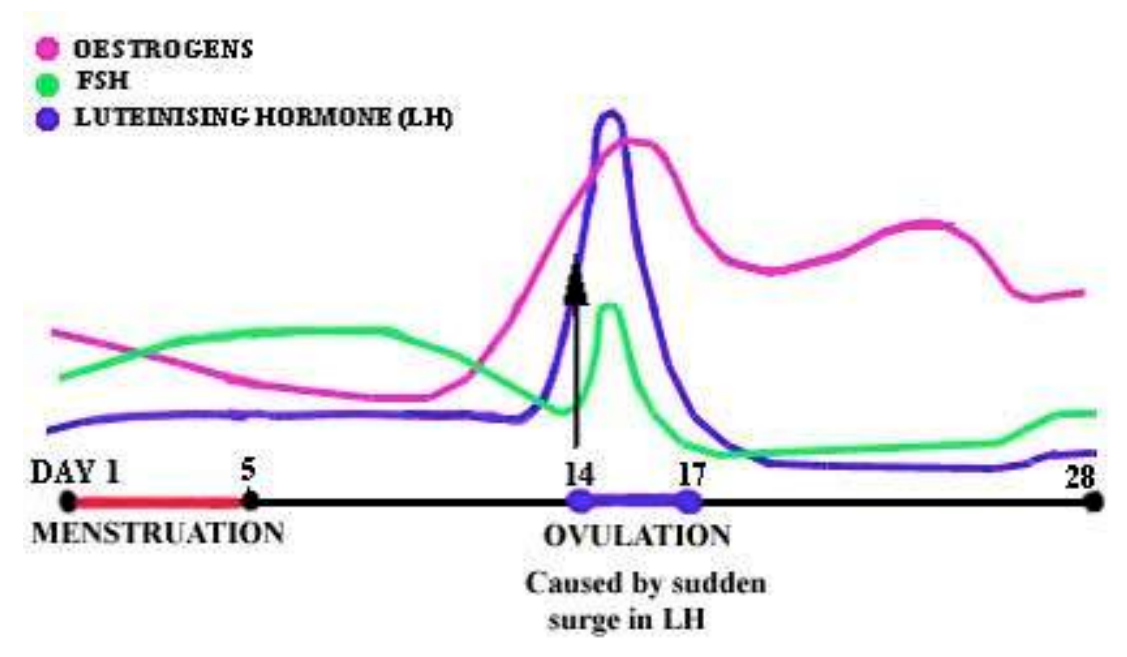

Sel telur yang telah dibuahi memerlukan beberapa hari untuk berjalan menuju tuba falopi, mencapai rahim dan pada akhirnya "menanamkan diri" didalam rahim. Kemudian, sel telur tersebut akan membelah diri dan memproduksi hormon Human Chorionic Gonadotrophin (HCG) yang dapat dideteksi dengan GEATEL. Hormon tersebut membantu pertumbuhan embrio didalam rahim. Jika sel telur yang telah dilepaskan tersebut tidak dibuahi, maka endometrium akan meluruh dan terjadinya proses haid berikutnya. Siklus menstruasi ratarata terjadi sekitar 28 hari, walaupun hal ini berlaku umum, tetapi tidak semua perempuan memiliki siklus menstruasi yang sama, kadang-kadang siklus terjadi setiap 21 hari hingga 30 hari. Siklus haid dapat dikelompokkan menjadi tiga kategori yaitu siklus haid pendek $<28$ hari, siklus haid normal $28-35$ hari dan siklus haid panjang $>35$ hari.

\section{Hukum Menggunakan Alat Kontrasepsi dalam Pandangan Islam}

Masalah keluarga berencana atau mengatur/mengendalikan kelahiran berbeda sekali dengan masalah kontrasepsi. Mengatur kelahiran bertentangan dengan memperbanyak keturunan, dan memperbanyak keturunan dianjurkan sekali dalam Islam. Allah SWT telah menganjurkan kepada umat Islam untuk meningkatkan angka kelahiran atau memperbanyak keturunan, bukannya mengatur atau mengendalikannya, yaitu dengan cara membatasi kelahiran. ${ }^{4}$

Menunda kehamilan berarti mencegah kehamilan, untuk memberikan jarak pada kelahiran sebelumnya. Membatasi kehamilan untuk selama-lamanya setelah memiliki anak yang diinginkan dengan mensterilkan rahim atau mengangkat rahim tanpa sebuah alasan yang dibenarkan oleh syariat, maka hukumnya haram, kecuali pada keadaan yang mengancam hidup perempuan atau laki-laki tersebut. 
Pada permasalahan pertama, mencegah kehamilan dan menunda jarak kelahiran dibenarkan, dengan alasan jarak kelahiran yang terlalu dekat dapat berdampak buruk bagi ibu dan anak, dengan alasan: Pertama Anak akan kekurangan suplai Air Susu Ibu (ASI). Ketika seorang ibu dalam keadaan hamil dan ada anak yang menyusui, maka produksi ASI akan berkurang, sekurang-kurangnya 6 bulan jika ingin hamil kembali setelah ibu melahirkan. Kedua kondisi ibu belum pulih benar untuk kembali melahirkan. Ketiga dibutuhkan tubuh yang fit untuk menghadapi persalinan berikutnya. Keempat, janin yang dikandung memiliki resiko lebih besar untuk premature, meninggal, ataupun cacat.

Salah satu cara untuk menjaga jarak kehamilan sehingga kemungkinan-kemungkinan di atas tidak terjadi adalah dengan menggunakan az'l (alat kontrasepsi). Pengertian Azl sendiri adalah mengeluarkan sperma laki-laki di luar vagina perempuan dengan tujuan untuk mencegah kehamilan. Pernyataan Badan Ulama Besar di Kerajaan Arab Saudi no: 42 tanggal 13/4 1396 H: Dilarang melakukan pembatasan keturunan secara mutlak. Tidak boleh menolak kehamilan jika sebabnya adalah takut miskin. ${ }^{5}$ Karena Allah SWT yang memberi rejeki yang Maha Kuat dan Kokoh. Tidak ada binatang di bumi kecuali Allah-lah yang menanggung rejekinya.

Mencegah kehamilan karena darurat yang jelas, seperti jika perempuan tidak mungkin melahirkan secara wajar dan akan mengakibatkan harus dilakukan operasi untuk mengeluarkan anaknya, atau melambatkan kehamilan untuk jangka waktu tertentu karena ada kemashlahatan yang dipandang suami-istri, maka tidak mengapa untuk mencegah kehamilan atau menundanya. Hal ini sesuai dengan apa yang disebutkan dalam hadits yang diriwayatkan sebagian besar para sahabat tentang bolehnya 'azl.

\section{Temuan Penelitian}

Karakteristik perempuan yang paling banyak menggunakan alat kontrasepsi IUD adalah perempuan yang berusia $>36$ tahun, terdapat 46 orang $(70,76 \%)$ dari 69 responden perempuan pengguna alat kontrasepsi IUD. Sedangkan pada perempuan pengguna alat kontrasepsi suntik sebagian besar berusia 26-35 tahun, terdapat 51 (60\%) dari jumlah 85 responden. Perempuan pengguna alat kontrasepsi IUD yang berusia 26-35 tahun hanya terdapat $23(33,33 \%)$ dari 69 responden, sedangkan pada perempuan pengguna alat kontrasepsi suntik terdapat 10 responden $(11,76 \%)$ yang berusia $<25$ tahun. Pada pembagian umur $>36$ tahun 
perempuan yang menggunakan alat kontrasepsi suntik terdapat 24 responden $(28,23 \%)$ dari 85 responden yang dijadikan sampel (tabel 2).

Tabel 2 :

Karakteristik Responden Menggunakan Alat Kontrasepsi IUD dan Kontrasepsi Suntik di Kecamatan Marpoyan Damai Pekanbaru

\begin{tabular}{lcccc}
\hline \multirow{2}{*}{ Karakteristik } & \multicolumn{4}{c}{ Alat Kontrasepsi } \\
\cline { 2 - 5 } & \multicolumn{2}{c}{ IUD } & $\mathrm{N}$ \\
\cline { 2 - 5 } & $\mathrm{N}$ & $\%$ & 10 & $11,76 \%$ \\
Usia Ibu : & - & - & 51 & $60 \%$ \\
a. < 25 Tahun & 23 & $33,33 \%$ & 24 & $28,23 \%$ \\
b. 26-35 Tahun & 46 & $70,76 \%$ & \multicolumn{3}{c}{ Suntik } \\
c. > 35 Tahun &
\end{tabular}

Sumber: Data Olahan 2012

Terdapat perbedaan dari masing-masing karakteristik haid yang dialami oleh pengguna alat kontrasepsi IUD dan Suntik. Dari hasil penelitian yang dilakukan bahwa siklus haid pada perempuan yang menggunakan alat kontrasepsi IUD cenderung mempunyai siklus haid yang normal yaitu 28-35 hari. Bahkan menurut hasil dari penelitian bahwa $65(94,20 \%)$ dari 69 perempuan pengguna alat kontrasepsi IUD mempunyai siklus haid yang normal. Sedangkan siklus haid pada perempuan yang menggunakan alat kontrasepsi suntik cenderung lebih pendek, terdapat 55 responden $(64,7 \%)$ perempuan yang mempunyai siklus haid pendek dan 30 responden (35,29\%) perempuan yang mempunyai siklus haid normal (tabel 3).

Tabel 3:

Karakteristik Responden berdasarkan Siklus Haid dengan alat kontrasepsi IUD dan Suntik di Kecamatan Marpoyan Damai Pekanbaru.

\begin{tabular}{llcccc}
\hline \multirow{2}{*}{ No } & \multirow{2}{*}{ Karakteristik Haid } & \multicolumn{2}{c}{ IUD } & \multicolumn{2}{c}{ Suntik } \\
\cline { 3 - 6 } & & $\mathbf{N}$ & $\%$ & $\mathbf{N}$ & $\%$ \\
\hline 1 & Siklus Haid : & & & & \\
& a. Pendek < 28 hari & - & - & 55 & $64,70 \%$ \\
& b. Normal 28-35 hari & 65 & $94,2 \%$ & 30 & $35,29 \%$ \\
& c. > 35 hari & 4 & $5,8 \%$ & - & - \\
\cline { 2 - 6 } & Total Jumlah & 69 & $100 \%$ & 85 & $100 \%$ \\
\hline 2 & Karakteristk haid : & & & & \\
\hline
\end{tabular}




\begin{tabular}{llcccc}
\hline & a. Menggumpal & 48 & $69,56 \%$ & 50 & $58,82 \%$ \\
& b. Flek-flek / bercak & 21 & $30,43 \%$ & 35 & $41,18 \%$ \\
\hline Total Jumlah & 69 & $100 \%$ & 85 & $100 \%$ \\
\hline $3 \quad$ Jumlah haid yang keluar & & & & \\
$\quad$ a. 2 x lebih banyak & 48 & $69,56 \%$ & 35 & $41,18 \%$ \\
$\quad$ b. Sedikit & 21 & $30,43 \%$ & 50 & $58,82 \%$ \\
\hline Total Jumlah & 69 & $100 \%$ & 85 & $100 \%$ \\
\hline
\end{tabular}

Sumber: Data olahan 2012

Hasil analisis statistik diperoleh $\mathrm{t}$ hitung sebesar 2,754 dengan nilai P sebesar 0,008 yaitu kurang dari 0,05 maka Ho ditolak dan Ha diterima. Dan dari nilai rata-rata yang diperoleh, siklus haid pada perempuan yang menggunakan alat kontrasepsi IUD sebesar 22,00. Sedangkan rata-rata siklus haid pada perempuan yang menggunakan alat kontrasepsi suntik sebesar 19,38 (tabel 4).

Tabel 4:

Hasil Analisis uji t.test independent siklus haid antara ibu yang menggunakan alat kontrasepsi IUD dengan Kontrasepsi Suntik

\begin{tabular}{lllrlcl}
\hline No & Alat Kontrasepsi & Rerata & SD & t hitung & Sig & Keterangan \\
\hline 1 & IUD & 22,00 & 4,048 & 2,754 & 0,006 & Signifikan \\
2 & Suntik & 19,38 & 3,563 & & & \\
\hline
\end{tabular}

Sumber: Data Olahan 2012

Menurut hasil penelitian dan dapat dilihat pada tabel 3 diketahui bahwa terdapat perbedaan dari masing-masing siklus haid dan karakteristik haid yang dialami oleh perempuan yang menggunakan alat kontrasepsi IUD dan suntik. Terdapat $94,2 \%$ perempuan pengguna alat kontrasepsi IUD yang mempunyai siklus haid normal. Siklus haid yang normal bisa terjadi akibat dari produksi hormone estrogen yang cukup. Siklus haid terjadi akibat dari pengaruh kerja hormon estrogen yang dimiliki oleh tiap-tiap individu. Namun berbeda pada perempuan yang menggunakan alat kontrasepsi suntik, siklus haid yang sering terjadi adalah siklus haid yang pendek yaitu kurang dari 28 hari.

Terdapat $55(64,70 \%)$ perempuan yang mempunyai siklus haid pendek dan $30(35,29 \%)$ perempuan yang mempunyai siklus haid normal. Hal itu disebabkan karena sebagian perempuan pengguna alat kontrasepsi suntik sering mengalami haid yang datang $2 x$ dalam jangka waktu 1 bulan dan secara otomatis siklus menstruasinya menjadi pendek yaitu kurang dari 28 hari. Siklus haid pendek (<28 hari) disebabkan oleh 
pengaruh kerja hormon estrogen. Akibat pengaruh kerja hormon estrogen, maka apabila produksi hormon berlebih akan menyebabkan siklus haid menjadi pendek.

Perbedaan bisa terlihat dari masing-masing cara kerja alat kontrasepsi IUD dengan kontrasepsi suntik. Cara kerja alat kontrasepsi IUD adalah mencegah pembuahan sel telur oleh sperma dan mencegah tertanamnya hasil pembuahan pada selaput lendir rahim. Untuk IUD yang mengandung $\mathrm{Cu}$ cara kerjanya adalah mengganggu pengambilan estrogen endogenous oleh mucosa uterus. Sedangkan cara kerja alat kontrasepsi suntik adalah menekan pengeluaran produksi estrogen. Dengan diberikan suntikan progesteron, diharapkan jumlah hormon progesteron menjadi lebih banyak dari estrogen. Namun pada saat terjadi menstruasi, hormon estrogen akan memuncak sedangkan hormon progesteron tidak memuncak. Maka apabila produksi hormon berlebihan akan menyebabkan siklus haid menjadi pendek. Selain itu cara kerja alat kontrasepsi suntik adalah: Pertama, Mencegah lepasnya sel telur dari indung telur. Kedua, Mengentalkan lendir mulut rahim, sehingga sperma sulit masuk ke dalam rongga rahim. Ketiga, Menipiskan selaput lendir agar tidak siap hamil. Salah satu penyebab haid tidak teratur adalah perubahan produksi kadar hormon ditubuh.

Perbedaan yang terjadi dari efek samping yang ditimbulkan akibat penggunaan alat kontrasepsi IUD dengan suntik sangat terlihat dalam tabel 3. Selain siklus haid karakteristik haid dari masing-masing alat kontrasepsi juga sangat terlihat perbedaannya. Pada pengguna alat kontrasepsi IUD karakteristik haid yang menggumpal lebih sering terjadi dibandingkan dengan karakteristik haid yang ditimbulkan dari pemakaian alat kontrasepsi suntik.

Terdapat $48(69,56 \%)$ perempuan pengguna alat kontrasepsi IUD yang mengalami karakteristik haid menggumpal dan karakteristik flekflek/spotting terdapat $21(30,43 \%)$ perempuan usia subur. Sedangkan pada pemakaian alat kontrasepsi suntik terdapat $50(58,82 \%)$ perempuan yang mengalami karakteristik haid menggumpal dan terdapat 35 (41,18\%) perempuan yang mengalami karakteristik haid berupa flek-flek/spotting.

Haid didefinisikan sebagai perdarahan pervaginam yang terjadi selama 1 episode setiap siklus dan akan kehilangan darah 40-100 $\mathrm{ml}^{2}$. Menurut hasil penelitian yang telah dilakukan bahwa terdapat 48 (69,56\%) perempuan pengguna alat kontrasepsi IUD yang mengalami haid yang $2 x$ lebih banyak dari haid biasa dan hanya terdapat 21 (30,43\%) dari 69 yang mengalami sedikit darah yang dikeluarkan pada saat haid. 
Cara kerja IUD seperti aborsi secara dini, dengan adanya benda asing di dalam rahim akan membuat rahim selalu berkontraksi sehingga bila terjadi pertemuan antara sel telur dengan sperma maka akan langsung dikontraksi oleh rahim untuk keluar. Hal ini mungkin yang menyebabkan jumlah haid perempuan pengguna alat kontrasepsi IUD menjadi $2 x$ lebih banyak. Pada pengguna unmedicated IUD, volume darah haid bertambah rata $50-100 \%$ diatas batas normal dan pada medicated IUD, bertambah 20-50\% diatas batas normal. ${ }^{6}$

Pada perempuan pengguna alat kontrasepsi suntik, terdapat 50 $(58,82 \%)$ perempuan yang lebih banyak mengalami perdarahan sedikit pada saat haid dan terdapat $35(41,18 \%)$ perempuan yang mengalami perdarahan $2 x$ lebih banyak dari haid biasa.

Gangguan siklus haid biasanya banyak terjadi pada perempuan usia subur akibat dari pemasangan alat kontrasepsi. Alat kontrasepsi IUD mempunyai efek samping yang sering terjadi yaitu haid yang lama, perdarahan bercak/spotting, dan nyeri pada saat haid.

Setelah dilakukan suatu penelitian pada 69 responden pengguna alat kontrasepsi IUD didapatkan jumlah 65 perempuan usia subur yang mempunyai siklus haid normal yaitu 28-35 hari.

Pada penggunaan alat kontrasepsi suntik juga terdapat efek samping yang sering terjadi yaitu gangguan haid, berat badan yang bertambah, dan sakit kepala. Dari hasil penelitian yang telah dilakukan di Kecamatan Marpoyan Damai Pekanbaru pada 85 responden didapatkan jumlah 55 perempuan usia subur yang mempunyai siklus haid pendek (<28 hari) dan 30 perempuan yang mempunyai siklus haid normal (28-35 hari).

Hipotesis yang akan diuji adalah "Terdapat Perbedaan Siklus Haid Antara perempuan yang Menggunakan Alat Kontrasepsi IUD dengan Kontrasepsi Suntik di Kecamatan Marpoyan Damai Pekanbaru". Hipotesis tersebut adalah hipotesis asli (Ha). Untuk keperluan pengujian hipotesis, hipotesis diubah menjadi nol hipotesis (Ho) sehingga menjadi “Tidak Terdapat Perbedaan Siklus Haid Antara perempuan yang Menggunakan Alat Kontrasepsi IUD dengan Kontrasepsi Suntik di Kecamatan Marpoyan Damai Pekanbaru".

Hipotesis tersebut diuji dengan menggunakan uji beda t-test independent. Dari tabel 4 didapatkan hasil analisis statistik diperoleh nilai P sebesar 0,006 yaitu kurang dari 0,05 maka Ho ditolak dan Ha diterima. Dengan itu didapatkan suatu kesimpulan bahwa terdapat perbedaan yang signifikan siklus haid antara perempuan yang menggunakan alat kontrasepsi IUD dengan kontrasepsi suntik di Kecamatan Marpoyan 
Damai Kota Pekanbaru. Dari nilai rerata yang diperoleh, siklus haid pada perempuan yang menggunakan alat kontrasepsi IUD sebesar 22,00. Sedangkan nilai rerata siklus haid pada perempuan yang menggunakan alat kontrasepsi suntik sebesar 19,38. Dengan hasil tersebut, dapat dinyatakan bahwa siklus haid pada perempuan yang menggunakan alat kontrasepsi IUD lebih baik dibandingkan dengan perempuan yang menggunakan alat kontrasepsi suntik. Menurut hasil analisis ini secara nyata siklus haid antara perempuan di Kecamatan Marpoyan Damai Pekanbaru berbeda menurut jenis alat kontrasepsi yang digunakan.

\section{Kebijakan Kelurga Berencana dan Hak Reproduksi Perempuan}

Keluarga Berencana pertama kali dijadikan program nasional pada masa orde baru, tujuan utama Program Keluarga Berencana secara makro untuk mengendalikan laju pertumbuhan penduduk dan menurunkan angka kelahiran, secara mikro mewujudkan ketahanan keluarga dan kesejahteraan masyarakat. Namun kebijakan pemerintah ini banyak mendapat kritik dari pemerhati masalah perempuan yang pelaksanaanya cendrung merugikan perempuan.

Bila diperhatikan, uraian mengenai kesehatan dan hak-hak reproduski sesungguhnya tidak hanya relevan dengan isu kesehatan reproduksi perempuan, melainkan juga dengan kesehatan perempuan pada umunya. Bahkan juga, dengan isu kedudukan dan posisi social perempuan dalam masyarakat yang yang masih menomorsatukan kepentingan dan perspektif laki-laki. ${ }^{7}$ Makna kesehatan dan hak-hak reproduksi perempuan terkait dengan hampir semua isu perempuan: pengendalian dari pihak lain, misalnya perkawinan yang diatur keluarga, tuntutan untuk memiliki anak laki-laki, keharusan menggunakan alat kontrasepsi/tidak menggunakan alat kontrasepsi, pengasuhan anak tanggung jawab perempuan, hingga marjinalisasi hak reproduksi perempuan lainnya.

Dalam penggunaan alat kontrasepsi, banyak perempuan harus menentukan pilihan kontrasepsi yang sulit, tidak hanya karena terbatasnya jumlah metode yang tersedia tetapi juga karena metodemetode tertentu mungkin tidak dapat diterima sehubungan dengan kebijakan nasional KB, kesehatan individual dan seksualitas perempuan atau biaya untuk memperoleh kontrasepsi. Setelah menggunakan alat kontrasepsi, perempuan harus dihadapkan pada efek samping bagi kesehatnnya, seperti yang terjadi pada sampel penelitian ini, pada perempuan yang menggunakan alat kontrasepsi suntikan siklus haid yang sering terjadi adalah siklus haid yang pendek yaitu kurang dari 28 hari. 
Terdapat $55(64,70 \%)$ perempuan yang mempunyai siklus haid pendek. Efek samping lain juga terjadi seperti Perdarahan bercak (spotting), yang dapat berlangsung cukup lama, jarang terjadi perdarahan yang banyak, sering menjadi penyebab bertambahnya berat badan dan dapat menyebabkan (tidak pada semua akseptor) terjadinya sakit kepala, nyeri pada payudara, 'moodiness, timbul jerawat dan berkurangnya libido seksual.

Mengacu pada hasil peneltian dan efek samping bagi kesehatan reproduksi sebagaimana telah disebutkan di atas, jelas bahwa implementasi program Keluarga Berencana hanya megedepankan secara kuantitatif, yakni mencapai sebanyak mungkin pengguna KB tanpa memikirkan kualitas layanan KB dan dampak pemakaian alat kontrasepsi terhadap kesehatan reproduksi para akseptor, yang mayoritas adalah perempuan. ${ }^{8}$

Selain birokrasi kecamatan atau kelurahan dan pusat kesehatan masyarakat, yang merupakan perpanjangan tangan negara dalam mencari pengguna alat kontrasepsi bagi perempuan yang tidak sanggup melawan pihak berwenang, perempuan-perempuan yang keadaan kesehatannya demikian terganggu, karena dipaksakan petugas, bisa mengakibatkan pendarahan terus menerus, seperti yang terjadi pada perempuan penggunan KB di Marpoyan Damai, yang terganggu siklus haidnya. Berbagai perlakuan di atas merupakan bukti kesewenang-wenangan negara terhadap hak reproduksi perempuan dan mereka dijadikan objek dan target sasaran untuk tujuan negara.

Melihat berbagai bentuk kekerasan terhadap perempuan sebagaimana diuraikan, telah dapat dibuktikan bahwa perempuan sangat rentan terhadap tindak kekerasan negara, terlebih jika terjadi konflik social di masyarakat. Perempuan kehilangan hak otonominya untuk mengatur, mengelola, dan mengendalikan aspek reproduksinya, padahal yang memahami kondisi dan kesehatan tubuh perempuan adalah perempuan itu sendiri.

\section{SIMPULAN}

Berdasarkan hasil penelitian dan pembahasan dapat disimpulkan bahwa terdapat perbedaan siklus haid antara perempuan yang menggunakan alat kontrasepsi IUD dengan kontrasepsi suntik di Kecamatan Marpoyan Damai Pekanbaru. Siklus haid pada perempuan yang menggunakan alat kontrasepsi IUD lebih baik dibandingkan dengan perempuan yang menggunakan alat kontrasepsi suntik yaitu dengan siklus normal 28-35 hari, sedangkan perempuan pengguna alat 
kontrasepsi suntik mempunyai siklus haid pendek yaitu $>28$ hari atau 2 kali dalam sebulan.

Dalam pandangan Islam, menggunakan alat kontrasepsi dibenarkan dengan tujuan untuk menunda kehamilan, bukan untuk menghentikan kehamilan. Perempuan harus diberi kesempatan untuk memilih kontrasepsi yang tepat dan baik untuk dirinya karena mereka akan menghadapi efek samping atas penggunaan alat kontrasepsi yang dipilihnya tersebut.

Pemerintah bertanggungjawab memberikan pelayanan yang maksimal. Sebagai bukti keseriusan negara dalam meminimalisir efek samping dari penggunaan alat kontrasepsi ini, perempuan yang terdampak selayaknya mendapat kompensasi dari Negara, mengingat derita yang dialami korban pada umumnya cukup serisus, baik secara fisik, psikologis dan seksual. Kebijakan negara mengenai Keluarga Berencana pada masa orde baru dan kinipun telah menargetkan tubuh perempuan dan menggunakan hak reproduski mereka. Perempuan dikorbankan demi mencapai tujuan politik pemerintah tanpa menetapkan kebijakan yang mengakomodasi perempuan.

Kedepan Indonesia mestilah memiliki komitmen membangun masyarakat yang anti kekerasan dan eksploitasi. Negara dan komponen bangsa hendaknya bersama-sama menkonstruksi berbagai kebijaakan dan perangkat hukum dengan merevisi dan menciptkana instrument hukum dan regulasi yang memberikan perlindungan kepada perempuan sehingga percepatan pencapaian kesetaraan dan keadilan bisa terwujud. Perlunya dibangun paradigma baru dalam keseluruhan kebijakan dan pelaksannya yang lebih berorientasi pada konsep dan perilaku guna percepatan gender quality dan gender equity.

\section{Endnotes:}

1 Sugiono, 2004. Metode Penelitian Bisnis, Bandung, CV AlfaBeta

2 Notoatmodjo, 2002; Metodologi Penelitian Kesehatan, Jakarta, PT. Rineka Cipta.

3 Azwar, S. 2003. Sikap Manusia Teori dan Pengukurannya, Edisi 11, Yogyakarta, Pustaka Pelajar

4 Fadly. 2007. Hukum Islam Tentang Kontrasepsi. http://arrahmah.com/read/2007/ 05/13/416-hukum-islam-tentang-kontrasepsi.html (online). diakses pada tanggal 25 Mei 2012

5 Moh Taufiq As'ad. Hukum KB. http://www.ydsf-malang.or.id/konsultasi/detail/76 _Hukum_KB. html (online) diakses pada tanggal 25 Mei 2012

6 Hartanto, H. 2003. KB dan Kontrasepsi, Jakarta, Pustaka Sinar Harapan

7 Romany Sihite. 2007. Perempuan, Kesehatan dan Keadilan, Suatu Tinjauan Berwawasan Gender, hlm. 59 
8 Tapi Omas Ihroni dkk. 2000. Penghapusan Diskriminasi Terhadap Perempuan. Hlm. 352

\section{DAFTAR PUSTAKA}

Arikunto, S. 2003. Prosedur Penelitian Suatu Pendekatan Praktek, Edisi revisi V. Yogyakarta: Pustaka Pelajar

Azwar, S. 2003. Sikap Manusia Teori dan Pengukurannya, Edisi 11. Yogyakarta: Pustaka Pelajar

BKKBN, 2011. Buku Saku Materi Konseling Bagi Petugas Lapangan. Jakarta: $\mathrm{BKKBN}$

BKKBN Provinsi Riau. 2012. Data Pelayanan Kontrasepsi per mix alat kontrsepsi januari s/d maret 2012

Dahlia, Y. 2004. Hubungan Tingkat Pendidikan Perempuan Kawin Usia Subur Dengan Pengetahuan Tentang Metode Kontrasepsi IUD. Yogyakarta: FK-UGM

Depkes. 2011. Buku Panduan Praktis Pelayanan Kontrasepsi. Jakarta: Depkes RI

Hartanto, H. 2003. KB dan Kontrasepsi. Jakarta: Pustaka Sinar Harapan

Ihroni, Tapi Omas dkk. 2000. Penghapusan Diskriminasi Terhadap Perempuan. Bandung: IKAPI

Notoatmodjo, S. 2002. Metodologi Penelitian Kesehatan. Jakarta: PT. Rineka Cipta

Riwidikdo, H. 2006. Statistik Kesehatan. Yogyakarta: Mitra Cendikia Press

Saifudin. 2003. Buku Panduan Praktis Pelayanan Kontrasepsi. Jakarta: YBPSP

Sihite, Romany. 2007. Perempuan, Kesehatan dan Keadilan, Suatu Tinjauan Berwawasan Gender. Jakarta: PT. Raja Grafindo

Sugiyono. 2006. Statistik Untuk Penelitian. Bandung: CV AlfaBeta

Sugiyono. 2004. Metode Penelitian Bisnis. Bandung: CV AlfaBeta

Varney, H. Kriebs, J. \& Gegor, C. 2003. Buku Saku Bidan, Jakarta, EGC. Wina, 2003. Faktor-faktor Yang Mempengaruhi Akseptor KB Memilih Metode Kontrasepsi IUD, Yogyakarta, FK-UGM

http:/ / www.fiqihperempuan.com/hukum-kb-dalam-pandangan-islam/) 